\title{
Decolonising Climate Change: A Call for Beyond- Human Imaginaries and Knowledge Generation
}

\author{
Sophie Chao \\ https://orcid.org/0000-0002-5434-9238 \\ University of Sydney, Australia \\ Dion Enari \\ Dhttps://orcid.org/0000-0002-3239-699X
}

Auckland University of Technology, Aotearoa/New Zealand

\begin{abstract}
This article calls for transdisciplinary, experimental, and decolonial imaginations of climate change and Pacific futures in an age of great planetary undoing. Drawing from our personal and academic knowledge of the Pacific from West Papua to Samoa, we highlight the need for radical forms of imagination that are grounded in an ethos of inclusivity, participation, and humility. Such imaginations must account for the perspectives, interests, and storied existences of both human and beyondhuman communities of life across their multiple and situated contexts, along with their co-constitutive relations. We invite respectful cross-pollination across Indigenous epistemologies, secular scientific paradigms, and transdisciplinary methodologies in putting such an imagination into practice. In doing so, we seek to destabilise the prevailing hegemony of secular science over other ways of knowing and being in the world. We draw attention to the consequential agency of beyond-human lifeforms in shaping local and global worlds and to the power of experimental, emplaced storytelling in conveying the lively and lethal becoming-withs that animate an unevenly shared and increasingly vulnerable planet. The wisdom of our kindred plants, animals, elements, mountains, forests, oceans, rivers, skies, and ancestors are part of this story. Finally, we reflect on the structural challenges in decolonising climate change and associated forms of knowledge production in light of past and ongoing thefts of sovereignty over lands, bodies, and ecosystems across the tropics.
\end{abstract}

Keywords: Pacific, Samoa, Papua, Indigeneity, climate change, more-thanhuman, imagination, storytelling, transdisciplinarity, decolonisation

eTropic: electronic journal of studies in the tropics publishes new research from arts, humanities, social sciences and allied fields on the variety and interrelatedness of nature, culture, and society in the tropics. Published by James Cook University, a leading research institution on critical issues facing the world's Tropics. Free open access, Scopus Listed, Scimago Q1. Indexed in: Google Scholar, DOAJ, Crossref, Ulrich's, SHERPA/RoMEO, Pandora. ISSN 1448-2940. Creative Commons CC BY 4.0 free to download, save and reproduce. To cite, include: Author(s), Title of Paper, Editors (Eds.) Special Issue Title (Special Issue) eTropic, volume, issue, year, pages and DOI: http://dx.doi.org/10.25120/etropic.20.2.2021.3796 
eTropic 20.2 (2021) Special Issue: Tropical Imaginaries and Climate Crisis

$\mathrm{T}$

he tropics are home to more than two thirds of the world's biodiversity. They house some 78 percent of all plant and animal species, 91 percent of all terrestrial birds, almost all known shallow-water corals, and an estimated 150,000 species yet to be officially documented (Barlow et al., 2018). These figures are all the more astounding given that the tropics cover only approximately 40 percent of the Earth's surface. Within this broad and diverse stretch, some tiny patches of forest have been found to host more plant and tree species than entire continents, providing crucial ecosystem services at global, regional, and local levels (Popkin, 2017).

But the tropics are in grave trouble. Fossil fuel extraction and exploitation, compounded with large-scale agriculture, mass industrial livestock production, and rampant deforestation, have rendered the region particularly vulnerable to global warming and its deleterious socio-environmental effects. Of the 32 countries at "extreme risk" from climate change, the top 10 are all located in the tropics (Law, 2019; Nugent, 2019). Myriad endemic species classified as critically endangered, threatened, or vulnerable by the International Union for the Conservation of Nature have been driven to the brink of extinction. ${ }^{1}$ The Golden Lion Tamarin Monkey. The Sumatran Orangutan. The Poison Dart Frog. The Bengal Tiger. The Leatherback Sea Turtle. The Javan Rhinoceros. The list goes on.

As co-authors of this paper, our engagements with climate change in the tropics have followed distinct yet intersecting personal and intellectual trajectories. For one author - Sophie Chao, a female scholar of Chinese and French descent - the visceral violence of climate change surfaced through long-term fieldwork in rural West Papua, where deforestation and monocrop oil palm developments are rupturing the intimate and ancestral kinships of Indigenous communities to their other-than-human kin: plants, animals, soils, water, ecosystems, and more (Chao, 2018a; 2019a; 2020; 2022 forthcoming). ${ }^{2}$ For the other author - Dion Enari, a Samoan male scholar - the effects of climate change represent an existential threat (K. M. Teaiwa, 2019). Samoa is disproportionately vulnerable to climate change (Fakhruddin et al., 2015). Enari's (Mother)land is not merely a commodity which his people live and depend upon. Instead, his (Mother)land is the source of his holistic being, strength, and guidance (Enari, cited in Chao, 2021a; Enari, 2021; Fa'aea \& Enari, 2021; Enari \& Faleolo, 2020). As her offspring, Enari and his people see it as their duty to protect and defend her.

\footnotetext{
1 See https://www.iucnredlist.org/.

2 In including the Indonesian-controlled region of West Papua within "the Pacific", we push against the disciplinary and political framing of West Papua as "South East Asia" or "Indonesia," which itself constitutes an artefact of settler-colonialism. Instead, we approach West Papua first and foremost as an Indigenous, Melanesian, and Pacific place - one that endures despite the dispossessory and discriminatory violence of settler-colonial rule.
} 
eTropic 20.2 (2021) Special Issue: Tropical Imaginaries and Climate Crisis

It was the coronavirus crisis - itself in many ways a symptom of humans' dysfunctional relationship to wildlife (Quinney, 2020) - that first brought us to think together respectively as curator and contributor of a special issue on COVID-19 in Oceania. ${ }^{3}$ In this, our second collaborative work, we draw from our insights and positionalities as Pacific scholars and climate dwellers to call for transdisciplinary, experimental, and decolonial imaginations of environmental crises and tropical futures in an age of great planetary undoing. Weaving together our personal and academic knowledge of the Pacific from West Papua to Samoa, we highlight the need for radical forms of imagination that are grounded in an ethos of inclusivity, participation, and humility. Such imaginations must account for the perspectives, interests, and storied existences of both human and beyond-human communities of life across their multiple and situated contexts, along with their co-constitutive relations.

We invite respectful cross-pollination across Indigenous epistemologies, secular scientific paradigms, and transdisciplinary methodologies in putting such an imagination into practice. In doing so, we seek to destabilise the prevailing hegemony of dominant scientific regimes over other ways of knowing and being in the world. We further draw attention to the consequential agency of beyond-human lifeforms in shaping local and global worlds, and to the power of emplaced storytelling in conveying the lively and lethal becoming-withs that animate an unevenly shared and increasingly vulnerable planet. The wisdom of our kindred plants, animals, elements, mountains, forests, oceans, rivers, skies, and ancestors are part of this story. Finally, we reflect on the structural challenges in decolonising climate change and associated forms of knowledge production in light of past and ongoing thefts of sovereignty over lands, bodies, and ecosystems across the tropics (Lemusuifeauaali'i \& Enari, 2021; Matapo \& Enari, 2021; Enari \& Rangiwai, 2021).

What we offer in this paper is an exploration of, or prolegomenon to, the kinds of collaborative, transdisciplinary, and situated thinking that we believe the planet and climate demand. The principles and questions we articulate are neither prescriptive nor exhaustive. Rather, we intend for them to be taken as spaces of possibility - as ontological, epistemological and methodological openings for (re)imagining and (re)connecting with increasingly vulnerable places, species, and relations (see de la Cadena, 2017; Escobar, 2019; Stengers, 2005). While much of what we offer is directly steeped in Indigenous philosophies, protocols, and practices, we acknowledge the inherent heterogeneity of Indigenous ways of being and thinking, as well as the creativity, resilience, and innovation that lie at the heart of Indigenous survivance and continuance (see Stewart-Harawira, 2018; Tuck, 2009; Vizenor, 1999). In the image

\footnotetext{
${ }^{3}$ The special issue sought to foreground the largely under-represented knowledges, experiences, and representational modes of Pasifika scholars, students, and communities about and amidst pandemic times (Eickelkamp \& Chao, 2020, Enari \& Fa'aea, 2020).
} 
eTropic 20.2 (2021) Special Issue: Tropical Imaginaries and Climate Crisis

of planetary biodiversity, we thus approach multiplicity and difference not as obstacles to collective thought and action, but rather as richly fertile grounds for unearthing multispecies futures at once less violent and more just.

\section{Imagination and Crisis}

The imagination and the climate crisis are profoundly entangled. Climate change, according to Indian novelist Amitav Ghosh (2016), is nothing less than "a crisis of culture, and thus of imagination." In a similar vein, American journalist David WallaceWells (2019) describes climate change as the tragic result of an "incredible failure of imagination." In taking the imagination as our central object of inquiry, we aim to push against the paralysing politics of despair that can so easily arise in the face of the climate crisis as an omnipresent and seemingly insurmountable "hyper-object" (Morton, 2013). In our view, it is not the failure of imagination itself that is the issue. Rather, the problem lies in the exclusionary scope of voices and beings heeded and represented by current dominant climate imaginaries - imaginaries that remain firmly anchored in, and perpetuate, the logic of human mastery over a "nature" recast as a passive, material substrate, meaningful only to the extent that it is useful to (certain) humans (Plumwood, 1993; Singh, 2018).

The voices obscured by dominant imaginaries include those of non-Western and Indigenous peoples of the tropics and elsewhere, who have always recognised the interdependencies of human and other-than-human beings, yet who bear the brunt of environmental crises in their everyday lives. They also include marginalised voices within marginalised communities - the women, the children, the non-human, and the elemental, present, past, and yet unborn (Chao, 2021b). These violent exclusions call for more capacious imaginaries that are accountable to the situated and connected worlds we inherit and transmit across time, generation, and species (Winter, cited in Chao, 2019b). They demand that we cease failing those whose imaginations are occluded from epistemic and moral purview. They prompt us to consider what ancestors we will become - and how we will be remembered - by imagined communities of life to come.

Following Amira Mittermaier, we deploy the term 'imagination' to refer to the varied and complex ways in which realities are conceptualised, fashioned, and contested (2011, p. 3). Imaginations are shaped by divergent socio-cultural contexts, materialecological terrains, and ideological and physical infrastructures that link the local to the global through partial and uneven connections. As a battlefield, the imagination expands possibilities of life within existing power dynamics, while challenging the hegemony of entrenched power asymmetries and their constitutive actors and institutions (Benjamin \& Glaude, 2018). Imagination entails experimenting with 
eTropic 20.2 (2021) Special Issue: Tropical Imaginaries and Climate Crisis

uncertainty, risk, and ambiguity, that together inflect the form and meaning of life and death amidst the climate crisis.

Imagination can birth unexpected and powerful modes of hope and resistance, that counter prevailing representations of tropical decline and disappearance. Take, for instance, the striking demonstrations of the 350-strong Fiji Team and fifteen other Pacific Island nations on the Pacific-wide Warrior Day of Action. In a powerful synergy of song, dance, and warrior energy, enacted at the heart of the West in Washington DC, the demonstrators marched the streets, chanting their rallying call in unison: "We are not drowning. We are fighting." 4 The imagination, then, is a call to collective action driven by ethical, material, and political prerogatives. It is a perspective on the world and the grounds for inhabiting the world otherwise. Recast as such, the imagination becomes a praxis of sovereignty and self-determination - one that calls for imaginative solidarity across place, time, and beings. In the remainder of this article we outline a set of principles towards achieving more capacious, inclusive, and relational ways of imagining climate and climate crisis. Each of these principles speaks to a particular facet of the natural world under threat. Each offers a tentative path for worlding worlds more critically, creatively, and capaciously.

\section{Relational Imagination}

Pacific Island ways of being are premised upon an holistic and relational harmony between humans, the environment, and the afterlife (Enari \& Matapo, 2020; 2021). The environment itself is composed of diverse inter-species and inter-elemental relations. Each actant within it plays a consequential role in shaping the worlds of others - from subterranean microbes and fungi, to oxygen-producing trees, groundchurning mammalian bioturbators, and pollinating birds and insects. There are no individual or autonomous actors within this world; rather, there are multiple, intra-active companionships bound in a relational ethic of kinship and care (see Arabena, 2010; Hau'ofa, 2008). As Māori scholar Makere Stewart-Harawira (2012) argues, nature's relational ontology produces its sacrality - a sacrality to which we owe respect, reverence, responsibility, and our very selves. This relationality speaks to the vital importance of reciprocity in sustaining more-than-human conditions of liveability. It also invites us to rethink the imagination itself as a relation that draws on, yet transcends, individual(istic) priorities, perceptions, and possibilities.

Imagining the climate (crisis) relationally entails considering the human and environmental relations that matter to our existence and to those of others both distant and proximate, alien and familiar. It draws into our conscience and consciousness the

\footnotetext{
${ }^{4}$ See https://350.org/350-pacific-we-are-not-drowning-we-are-fighting/.
} 
eTropic 20.2 (2021) Special Issue: Tropical Imaginaries and Climate Crisis

multiplicity of lives that must be sustained in order for our own to be rendered liveable. It calls for us to reflect seriously upon how and whether our existence as human individuals and collectives offers nourishment to non-human beings as companion species and significant others (Chao, 2021c; Haraway, 2008). In tracing the ecologies of matter and meaning that give flesh to human and beyond-human being, we take seriously the question of what makes a life worth living. In doing so, we hone a sense of curiosity for lives lived otherwise and elsewhere. Curiosity in turn paves the way for care - a recognition that care for the other is always also care for the self (see Chao, 2021d; Puig de la Bellacasa, 2017).

Imagining the climate crisis relationally reframes individual, everyday acts through their spatio-temporally distributed impacts upon other planetary dwellers - from what we eat and drink, to what we think is worth doing and knowing. We become aware of the multiple imaginaries, actors, and forces shaping the climate crisis - communities, states, corporations, researchers, activists, markets, technologies, ideologies, and more. At some junctures, situated imaginaries fall into alignment, offering avenues for imaginative alliance and cosmopolitical action (see Stengers, 2005). At others, imaginaries come into friction, highlighting incommensurabilities and incompatibilities across different interests, values, and norms (see Tsing, 2005). In each instance, we may ask: which lives and ecologies are at stake, sacrificed, or prioritised by our imaginations? What do these imaginations do in and for the world? What place is there for my imagination in yours, and yours in mine? In this unevenly connected and ongoingly threatened world, what constitutes our common ground?

\section{Beyond-Human Imagination}

Reframing the imagination as relational in turn invites an imagination beyond the human. By this we mean an imagination that takes seriously the possibility of otherthan-human entities as both objects of harm and subjects of justice. Indeed, the ravaging effects of climate change on planetary ecosystems makes it clear that it is not only humans who can suffer violence and injustice (Winter \& Troy, 2020). The scale of devastation to forests, animals, and water systems prompted by climate change foregrounds the need for conceptions of wellbeing, care, and dignity that consider the interests of all earth beings - not as autonomous, individuated wholes; but rather, as parts and partners in processual, more-than-human becomings (see Celermajer et al., 2020; Chao, 2021f; Haraway, 2016; Moore, 2020).

At the same time, a beyond-human imagination raises thorny questions about the possibility of apprehending or entering the perceptual lifeworld of non-human beings with whom we share the planet. It brings us to consider the potential and limitations of anthropomorphic projection in understanding and representing non-human existence. 
eTropic 20.2 (2021) Special Issue: Tropical Imaginaries and Climate Crisis

It also challenges us to expand what we mean by "beyond human" to include not just other "life" forms, or bios, but also elemental bodies such as oceans, rivers, mountains, and soils, that many Indigenous peoples consider to be equally animate and sentient (Argyrou \& Hummels, 2019; Bawaka Country et al., 2015; Martuwarra RiverofLife et al., 2020). And it invites us to ask: how do we learn to listen to the beyond-human world? Who can speak with and for the beyond-human world? And what should we do with the stories entrusted to us by the beyond-human world?

Taking these questions seriously is critical in eschewing human exceptionalism and its devastating impacts on the natural world. It demands the cultivation of an intellectual and ethical openness to the possibility of other-than-human sentience, will, and desire, and a repositioning of the "human" as one within a broad spectrum of matter and life in both deep and present time. Beyond-human imagination is therefore also a practice of humility - a recognition that other beings, too, have rich and meaningful lifeworlds, even if we can never fully access or understand them. This is not a humility that belittles the human, nor is it one that excludes the human from the natural world. Rather, it is an inclusive mode of humility that enlarges our conceptual and imaginative worlds by accommodating other Others in their myriad animal, vegetal, and elemental manifestations.

A beyond-human imagination is in turn an invitation to rethink the way we write and represent the natural world (Chao, 2018b). How, for instance, do we communicate the fleshly liveliness of plant and animal beings? How do we write nature in the active voice (Plumwood, 2009) without letting the script over-write/ride the alterity of otherthan-human life (see also Perez, 2020)? How do we come to understand beyondhuman lives inscribed upon rock, water, feather and bark? In these beyond-human decipherings, how do we weave description with de-cryption? When it comes to storying multispecies worlds, should we describe, or de-scribe?

\section{Storied Imagination}

Stories offer a potent medium for (re)imagining the climate relationally and beyond the human. In West Papua, where Chao has been conducting research among Indigenous Marind people, species do not exist as categories but rather as stories. Their lifeways are irreducible to fixed or bounded taxonomies. Rather, species come into being through richly complex and orally transmitted narratives that flesh out their origins, movements, subsistence, and social and emotive lives. Individual plants and animals have stories, as do plant and animal collectives, ecosystems, and even entire territories. Stories multiply as one travels the living landscape, intersecting with one another in a dense meshwork of intertwined experiences, events, and memories. The cassowary's story becomes the river that becomes the canopy that becomes the tree- 
eTropic 20.2 (2021) Special Issue: Tropical Imaginaries and Climate Crisis

kangaroo that becomes the child that becomes the sago palm that becomes the storyteller. Together, humans and other-than-humans partake in one ongoing and constantly transforming multispecies story.

Stories matter in (re)imagining climate because they participate in the worlds that they describe. As multispecies ethnographer Thom van Dooren notes, "fleshier, livelier stories make us care more" (2014, p. 10; see also van Dooren \& Rose, 2016). Stories are not just cultural artefacts - they are also political tools that can compel readers and auditors to situate the world, and themselves within it, otherwise. Stories can move, inspire, sadden, shock, or enlighten us. Stories are collectively produced and passed on across generations as intangible heritage about lively tangible worlds. In the words of Solomon Islander and political theorist Tarcisius Kabutaulaka, "stories frame our beliefs, understandings, and relationships with each other and the world around us...our lives are interwoven stories...we live in an ocean of stories" (2020, p. 47). Stories, then, are not "make-believe" in the sense of fictional fantasies disconnected from the worlds they describe. But stories can make us believe in, and achieve, better shared worlds. As such, stories constitute powerful instruments for collective action amidst rampant environmental destruction and its rippling effects across species lines.

Storying extinction, loss, and crisis reminds us of our responsibilities towards the more-than-human world - even as words may fail us in describing their force and scale (see Chao, 2021f). Stories, when repeated and passed on, invite us to commemorate the beings whom we bring forth in our utterances, and who are critically vulnerable to planetary unravellings. In repeating the names and stories of organisms pushed to the edge of extinction, we refuse to forget their liveliness, symbiotic existence, and consequential presence. In telling stories with others - our friends, family, readers, and audiences - we also refuse to singularise narratives. Instead, we invite the participation of all who are in one way or another invested in the climate crisis and its more-than-human chains of living and dying. Drawing into stories our peoples, oceans, forests, mountains, animals, and ancestors, we fa'aola (bring to life) the urgency of the climate crisis and the responses it demands of us.

\section{Multi-Sensory Imagination}

Storying beyond-human worlds involves engaging sensorially with the environment in crisis. Rather than adopting a distanced, disembodied, and putatively omniscient perspective on the world, multi-sensory imagination takes as its starting point the literal grounds in and upon which planetary life arises, transforms, senses, and senesces. It also moves away from framing the imagination as a purely conceptual or ideological praxis, conjured by our (human) minds and detached from our (more-than-human) 
eTropic 20.2 (2021) Special Issue: Tropical Imaginaries and Climate Crisis

surroundings. Instead, a multi-sensory imagination calls for a phenomenological immersion in the material worlds that we are part of - its textures, smells, sounds, sights, and movements (Chao, 2017). It marks a shift away from the abstract and deep into the wet, sticky, and messy textures of multispecies lifeworlds - one that demands, in anthropologist Anna Tsing's (2014) terms, that we learn to "look around" and not just "look ahead."

This art of sensory attunement involves a certain slowing down of thought and movement. As the famous Marind proverb goes, "Stop talking, start listening. Stop thinking, start walking." What Marind are calling for here is a silencing of the self that makes space for the voices of others - the ripple of a river, the shy whistle of a bird, or the gentle sway of a palm frond. This multispecies sensorium is powerfully captured also in the words of Kabi, an Indigenous Gimi man living just across the border from Marind in Papua New Guinea. When asked by environmental anthropologist Paige West how he knows the forest, Kabi responds: "My eyes, my ears, my nose, my mouth, my teeth, my skin, my father, my bones" (West, 2006, p. 237). Like Kabi, we might learn to know and imagine the climate through our bodily flesh and fluids - the air that we breathe, the waters that nourish us, and the soils that hold us.

To imagine the climate sensorially eschews the ocularcentrism so central to Western ways of knowing and representing the world (Howes, 2003; Pandya, 1990). Visual observation matters - but there are other ways of engaging with the environment. Writing of her native Hawaiian epistemologies, for instance, Elder, scholar, and activist Manulani Aluli-Meyer (2001) describes listening as central to paying attention to the rhythms and patterns of the more-than-human world and to becoming actively aware and respectful of its spiritual force and presence. Through sound and other sensory modes, we discover the vulnerability of our own flesh and form, and of the more-thanhuman beings whom we behold, hear, touch, smell, and taste. We also learn something new and different in the process.

Every sensory receptor matters to every form of matter because it allows us to gain a better understanding of each other. For this reason, a Samoan Chief pondering an important decision will swim in the water and cast his concerns to the ocean. The Chief engages their body and spirit in the ocean, such that the ocean is able to understand their concerns and provide its answer through the sounds it makes and the way it moves. In touch particularly, we learn something central to more-than-human existence - that one cannot touch without being touched (Puig de la Bellacasa, 2009). Touch, like species and climates, is inherently relational and interagentive. It changes the toucher and touched in equal, if different, measure. It is an invitation to let ourselves be touched by crisis and loss in order to fashion more gentle ways of touching each other in multispecies sensoriums to come. 
eTropic 20.2 (2021) Special Issue: Tropical Imaginaries and Climate Crisis

\section{Emplaced Imagination}

To imagine is to expand worldly possibilities - to practice a form of speculative nomadism through which new and different futures can be envisioned and enacted. But imaginations are also rooted in landscapes and places that, as Pacific cosmologies teach us, are always at once physical, ecological, historical, cultural, and spiritual (Banivanua Mar, 2012; Chao, 2019c; Leach, 2003). An emplaced imagination recognises the dialogical relationship between global and local realities. It attends to the embeddedness of time, history, and pasts within the semiotic materiality of local landscapes. To practice an emplaced imagination is therefore to situate the climate crisis within spatio-temporal framings that are not universal or linear, but rather culturally shaped and therefore plural and overlapping (Anderson et al., 2018). In doing so, we recognise the embeddedness of time itself within place and its historical transformations. Looking forward into tropical futures becomes a looking back through the very materiality of the changing world. In the words of Tongan and Fijian writer and anthropologist Epeli Hau'ofa, "We cannot read our histories without knowing how to read our landscapes (and seascapes)" (2008, p. 73; see also Winter, 2019).

Emplacing the imagination draws our attention to the relationship between place, belonging, and identity, and how this relationship is forged through the place-making practices of both human and beyond-human dwellers. It literally grounds the imagination in the soils and waters from which more-than-human life is borne, inviting us to think with ecological formations that transcend species-specific analyses. Internalising Hau'ofa's words, we may imagine climate futures through forests, or oceans, or rivers. We may trace through these beyond-human bodies our worldly connections to distant places and peoples. In navigating these landscapes, we learn to imagine not just with our minds and thoughts, but also with our feet, hands, sweat, and breath. We take stock of the places that matter to our sense of self and dignity collective and individual - and what is at stake in their destruction.

Violent histories of settler-colonial capitalism are inscribed upon tropical landscapes their nomenclatures, infrastructures, and ecosystems (Banivanua Mar, 2012; McKittrick \& Woods, 2007). These toponymic signatures communicate hegemonic imaginaries of extraction, extinction, simplification, homogenisation, and domination over people, species, and place. An emplaced imagination reveals the conjoined logic of racialisation and exploitation that continues to shape lives, deaths, and afterlives across the tropics. It foregrounds the slow, spectacular, and regimented violence wrought by anthropogenic transformations in the shadow places of industrial capitalism (Plumwood, 2008) - the monocrop oil palm plantations, abyssal gold and copper mines, acidified oceans, depleted forests, and eroded soils. In these places, the obliteration of some species accompanies the exploitation of others, who find 
eTropic 20.2 (2021) Special Issue: Tropical Imaginaries and Climate Crisis

themselves reduced from lively historical actors to deadened and deadly unpaid labour, or "Cheap Natures" (Moore, 2015). Erasures and absences matter to an emplaced imagination. They make us ask: who has been uprooted and transplanted to make today's places possible? What are the centres and peripheries of today's landscapes, and to whom are they (in)hospitable? How do these places nourish us, and how do we in turn nourish them?

\section{Reflexive Imagination}

Imagining the climate with others, and otherwise, demands that we reflect seriously on our own positionality as scholars, practitioners, and planetary dwellers. In particular, it draws attention to the multiple power fields within which research takes place. These include the power dynamics at play within the heterogeneous communities we learn from, between researchers and their interlocutors and the institutions, values, and status they represent, and also between knowledge systems across different local, disciplinary, and institutional settings. Each of these facets shapes the way in which knowledge is produced, shared, received, and acted upon. Reflexivity is thus at once a political, ethical, and methodological practice. It demands that we continually and critically reflect not just on the questions we ask about climate change, but also how and with whom we formulate and answer these questions (Archibald et al., 2019; Coburn et al., 2013; Nabobo-Baba, 2008; Tuhiwai Smith, 2012).

The relationship between ethnography and theory offers one potent space for (re)imagining climate change reflexively. All too often theory is produced in and by the Global North based on realities that supposedly just "happen" in the Global South. In the process, Indigenous peoples' own theories and philosophies of environment and environmental crisis become colonised by Western paradigms, concepts, and idioms. As Banaban and African-American scholar Katerina Teaiwa notes, the incorporation of Pacific ways of knowing and being into pre-existing and dominant epistemic frames is far from a new practice (2006, p. 74). It perpetuates what Māori scholar Makere Stewart-Harawira (2013) calls "knowledge capitalism," or the instrumentalisation of Indigenous epistemologies in the interest of institutional ends that do not account for (let alone serve) the interests of Indigenous peoples themselves.

Imagining climate change reflexively thus demands a shift away from the positioning of Indigenous peoples as "research-subjects" and instead as joint producers of knowledge. This includes not just the communities in the field whom we work with, but also Indigenous scholars and scholarship, that tend to be obscured by dominant canons and associated intellectual genealogies (Gegeo \& Watson-Gegeo, 2002; Hau'ofa, 1975; Te Punga Somerville, 2021). Decolonising our texts and theories is 
eTropic 20.2 (2021) Special Issue: Tropical Imaginaries and Climate Crisis

imperative in challenging the White and Western monopoly over knowledge and the imagination and in doing justice to Indigenous intellectual agency. Importantly, such an approach does not entail a complete rejection of all non-Indigenous theory. Rather, as Māori scholar Linda Tuhiwai Smith explains, decolonising research means putting Indigenous peoples' concerns at the centre and approaching research "from Indigenous peoples' perspectives, and for Indigenous peoples' purposes" (2012, p. 89). In doing so, we reimagine epistemology beyond what or how one knows, to what is "worth knowing" in a changing world (Aluli-Meyer, 2001, p. 125; see also Gegeo \& Watson-Gegeo, 2001).

When we research and teach climate change, we should therefore ask ourselves: whose voices and knowledge are we drawing from? How is this represented in our citations and acknowledgements? Whose voices are missing from the conversation, and why? What makes us decide to cite one scholar over another? What meanings and categories grow organically out of the research, and which are imposed? What impression of ownership over concepts and ideas is created in the process? What is this knowledge for and whom does this knowledge serve?

\section{Transdisciplinary Imagination}

The climate crisis is a multi-faceted problem, therefore it demands transdisciplinary responses. ${ }^{5}$ As transdisciplinary scholars ourselves, our research engages with insights, methods, and theories derived from a wide array of fields: anthropology, plant science, history, education, and Indigenous studies, among others. Importantly, we call here for a transdisciplinary practice that is synthetic and transformative, rather than purely additive or complementary. By this we mean an engagement with other fields that invites us to seriously and critically rethink the premises and assumptions underlying the diverse ways we approach, understand, and act upon the world. Such a transdisciplinary practice encourages us to reconsider the questions we believe matter - why, in whose interests, and with what intended or contingent effects. It entails the difficult but necessary labour of translating our ideas beyond familiar audiences to make these ideas intelligible, accessible, and relatable to broader publics. It also makes us reflect on what counts as knowledge, how different knowledges and knowledge production systems sit within prevailing hierarchies of worth, legitimacy, and value, and what can be done to destabilise the assumed power and validity of some knowledge regimes over others.

\footnotetext{
${ }^{5}$ The term 'transdisciplinary' captures the practice of thinking within, across, and beyond disciplinary fields that we deem essential to reimagining climate futures. In this regard, transdisciplinarity differs to some degree from 'interdisciplinarity', which communicates a form of thinking operating across, but not necessarily transcending, the boundaries of existing disciplinary fields, and 'multidisciplinarity', which draws from different disciplines but does not question their respective epistemological premises.
} 
eTropic 20.2 (2021) Special Issue: Tropical Imaginaries and Climate Crisis

In the context of climate change, transdisciplinarity can help challenge the assumed supremacy of secular science over other ways of knowing. In offering this argument, we are wary of the risks of reductionism inherent in assuming West and non-West epistemic binaries (see Carrier, 1995). We also acknowledge the plurality at play within dominant secular scientific paradigms, the situated construction of scientific knowledge, and the politically inflected ways in which this knowledge has been produced, deployed, and critiqued by both Western and Indigenous philosophers and scientists (e.g. Barad, 2007; Haraway, 1989; Latour, 2010; Stengers, 2015; TallBear, 2013). We further depart from the erroneous assumptions that secular scientific and other epistemologies are incompatible (Kimmerer, 2014), that secular science cannot lend itself to local interpretation or Indigenisation (Gegeo \& Watson-Gegeo, 2001), that Indigenous epistemologies are static and/or irrational (T. K. Teaiwa, 2006; T. K. Teaiwa \& Joannemariebarker, 1994), and that there is no such thing as "Indigenous science" (Poelina, 2020).

What we do wish to emphasise is that Indigenous and other non-Western epistemologies have frequently been, and continue to be, rendered secondary to secular science when classified as "Traditional Ecological Knowledge" and "Indigenous Wisdom". We do not dismiss the substance subsumed under these labels (frankly, we could all do with a bit more wisdom) but rather highlight how these labels unwittingly conjure the primacy of secular scientific regimes - even as groundbreaking secular scientific discoveries often reveal in other idioms what Indigenous sciences have always known. That plants communicate with each other. That carefully controlled fires nourish the soil. That killing environments eventually kills people.

A transdisciplinary imagination therefore demands that we decolonise knowledge itself from bounded and hierarchised "disciplines", literal and metaphoric. Discipline, after all, lies at the heart of the imperial-capitalist logic and its extractive ethos. Discipline within this logic positions the "human" as master and the non-human as resource. Discipline, in many ways, negates the possibility of freedom, experimentation, and creativity. The climate crisis itself exemplifies the deadly endpoint of discipline - real or illusory - over the natural world. In doing so, the climate crisis invites an emancipation of knowledge from the disciplinary strictures that determine where knowledge belongs and whether it is valued.

\section{Radical Imagination}

As climate change intensifies, the tropics are becoming increasingly vulnerable to extreme droughts, floods, and high-intensity cyclones. Forest and marine biodiversity struggle to adapt to rapidly changing environments, with over half of these species likely to become locally or globally extinct in the near future (Salisbury, 2017). Coral 
eTropic 20.2 (2021) Special Issue: Tropical Imaginaries and Climate Crisis

reefs in particular have, and will continue, to suffer unprecedented mass bleaching episodes as a result of rising sea-surface temperature extremes. These rich ecosystems may disappear entirely by 2050 . Meanwhile, Pacific livelihoods, food and water security, and local economies, are jeopardised by growingly unpredictable climate conditions. Climate refugeeism, along with rural impoverishment, are on the rise (Harding \& Penny, 2020). Human displacement and dispossession are compounded by the obliteration of locally meaningful stories, cultures, and relations with the beyond-human world, that in turn erode Pacific ways of being, becoming, and belonging.

These radical times call for radical imaginations. Our use of the term "radical" is inspired by the work of Native Studies and Science and Technology Studies scholars Hi'ilei Julia Kawehipuaakahaopulani Hobart and Stephanie Maroney, who call for "radical care" in a time of unprecedented social and environmental crises. Radical care, Hobart and Maroney write, "provides glimmers of hope amidst precarious worlds, even as it remains embedded with systemic inequalities and hegemonic power structures. As a form of strategic audacity, radical care is a refusal not to care and an imagining of an otherwise despite dark histories and potentially darker futures" (Hobart \& Kneese, 2020, pp. 2-3; see also Simpson, 2007). In the context of climate imaginaries, a radical imagination seeks to counter the crippling force of political apathy and the sense of help/hopelessness accompanying the seemingly insurmountable scales of loss and destruction that surround and haunt us. To imagine radically is to refuse not to imagine better futures and to insist on acting and interacting with the natural world in ways that can enable these futures to materialise.

A radical imagination attends in equal measure to experiences of loss and disempowerment as it does to practices of resilience and resistance, as these manifest across grassroots and transnational settings. In doing so, a radical imagination subverts what Anangax scholar Eve Tuck (2009) calls "damage-centered" approaches, or approaches that elide Indigenous forms of survivance by focusing solely or primarily on socio-cultural and ecological violences and endings (see also Vizenor, 1999). Instead, we need to tell the story of climate change through Pacific acts of struggle, solidarity, and self-determination - the fighting, and not (just) the sinking, to echo the 350 Fiji Team's slogan. These modes of resistance take multiple forms - organised and global climate activism, sustained regional cultural and social practices, resilient local foodways, intergenerational knowledge transmission, and more. As emergent and collective expressions of cultural and political creativity, these acts are just as central to the story of climate change as the climate crisis itself.

Radical imaginations are integral to the way we narrate and represent the climate crisis. They invite experimental forms of expression within and beyond the written text 
eTropic 20.2 (2021) Special Issue: Tropical Imaginaries and Climate Crisis

- oral storytelling, poetic recitation, everyday rituals of care, dream-sharing, artistic production, among others. They open space for critically thinking and emotionally feeling our way through (and potentially out of) crisis. These feelings call for the crafting of narratives that lie outside the ambit of conventional representational modes but that do better justice to crisis' emotional toll. We might, for instance, decide to write manifestos, laments, prayers, or requiems - texts that don't (just) analyse or explain (away) the world, but that make space to mourn, laugh, praise, celebrate, weep, and scream the world. When it comes to representing the agency of beyond-human beings, we might take the lead of Pacific scholars and activists who insist on recognising places and ecosystems as legitimate producers of knowledge in their citational practices (e.g. Bawaka Country et al., 2015; Martuwarra RiverofLife et al., 2020). In doing so, we inch a little closer to acknowledging and embracing the authority of beyond-humans as co-creators of the worlds we inhabit. We open space for thinking and theorising not just about or for the natural world, but rather with it.

A radical imagination does not shy away from engaging with or addressing the growing uncertainty and precarity of climate presents and horizons to come. Rather, it takes this uncertainty as the very grounds from which to fashion unexpected forms of hope, emergence, and resurgence. Radical hope is radical in that it persists even when the object of hope remains unintelligible, unachievable, or unknowable, and perhaps only fully graspable in retrospect (Lear, 2006). It entails a recognition that better worlds are possible and necessary, but never certain, guaranteed, nor ever entirely determined by human agency. Forging radical hope and inclusive imaginations of climate futures thus demands both courage and humility - a cultivation of active accountability towards the environments we become-with and an awareness that climates and futures are always already crafted with and by beyond-human actors.

\section{Towards a Decolonial Imagination}

In this article, we have sought to outline a set of guiding practices and principles that we believe can help pave the way for more expansive, relational, and inclusive climate imaginaries. These practices and principles aim to counter the ethnocentrism, individualism, and hierarchism of dominant climate imaginaries that are no longer (indeed never have been) fit for purpose. They grow out of our ongoing collaborations and conversations with Indigenous, Pasifika, and Papuan communities, who find themselves most deeply and directly mired in the fraught predicament of the climate crisis. They invite imaginative solidarities across places and times that, in the image of the climate itself, can serve to unite, rather than divide us. These practices and principles call for a rethinking of our relation to the more-than-human world - one that includes and recognises Pacific cosmologies and philosophies in which being human is always becoming-with beyond-human others. To neglect these more-than-human 
eTropic 20.2 (2021) Special Issue: Tropical Imaginaries and Climate Crisis

becomings is to strip the world of its wonder and enchantment - its ongoing and multiple forms of sympoietic creation, formation, and relation. This ecological and ideological flattening calls for a radical turn (or tropos, the etymological root of "tropics") away from utilitarianism and anthropocentrism, and towards multispecies, future flourishings.

Decolonising climate imaginaries demands a radical shift in the order of matter and thought - a radical change in direction and action. This is no small task. As Fijian historian Tracy Banivanua Mar (2016) notes, decolonisation in the Pacific has not been an historic event, but rather, is a fragile, contingent, and ongoing process continuing well into the postcolonial era. In West Papua, decolonisation remains an ongoing object of struggle for Indigenous peoples who continue to be denied the right to selfdetermination, dignity, and freedom (Chao, 2019). Climate imaginaries, too, are profoundly shaped by violent histories of racial imperialism, colonialism, and capitalism, and their residual afterlives. As Potawatomi scholar Kyle Powys Whyte (2017) reminds us, the climate crisis for Indigenous peoples is less a new phenomenon than a "colonial déja-vu" - a perpetuation of long-standing processes of dispossession, displacement, and disempowerment (see also Davis \& Todd, 2017; Stewart-Harawira, 2012).

Grappling with the climate crisis demands that we account for these longer histories of violence that continue to undermine Indigenous imaginative and political sovereignties in the tropics and beyond. These histories of violence materialise in various forms in our everyday life - from the commodities we purchase and consume, to the operational infrastructures of the institutions we work for or within, to the methodologies we deploy in our research. They point not to a lack of imagination, but to the structural factors that render some imaginations more powerful and lethal than others.

Transforming the imagination from deadly battlefield to flourishing future calls for a collective reckoning amidst the ruin and rubble generated by imperial-capitalist projects of scale, desire, and extraction. In this reckoning, no position is ever entirely innocent or pure (Shotwell, 2016) and no entanglement ever entirely reciprocal or just (Giraud, 2019). To imagine the climate otherwise is to stay with the trouble of interand intraspecies asymmetries but also to work creatively and collaboratively towards a less violent sharing of suffering across species lines (Haraway, 2008). In this, we may do well to live by the eloquent quote so widely used across the Pacific and pronounced by prominent Matai (chief) and former Head of State of Samoa, His Royal Highness Tui Atua Tupua Tamasese Efi (2003, p. 51): 
eTropic 20.2 (2021) Special Issue: Tropical Imaginaries and Climate Crisis

I am not an individual; I am an integral part of the cosmos. I share divinity with my ancestors, the land, the seas, and the skies. I am not an individual, because I share a tofi [inheritance] with my family, my village, and my nation. I belong to my family and my family belongs to me. I belong to a village and my village belongs to me. I belong to my nation and my nation belongs to me. This is the essence of my sense of belonging. 
eTropic 20.2 (2021) Special Issue: Tropical Imaginaries and Climate Crisis

\section{References}

Aluli-Meyer, M. (2001). Our Own Liberation: Reflections on Hawaiian Epistemology. The Contemporary Pacific, 13(1), 124-148. https://doi.org/10.1353/cp.2001.0024

Anderson, W., Johnson, M., \& Brookes, B. (Eds.). (2018). Pacific Futures: Past and Present. University of Hawai'i Press. https://www.jstor.org/stable/i.ctvvn4fi

Arabena, K. (2010). All Knowledge is Indigenous. In V. A. Brown, J. A. Harris, \& J. Y. Russell (Eds.), Tackling Wicked Problems: Through the Transdisciplinary Imagination (pp. 260270). Earthscan.

https://www.taylorfrancis.com/books/edit/10.4324/9781849776530/tackling-wickedproblems-john-harris-valerie-brown-jacqueline-russell

Archibald, J-A., Lee-Morgan, J., \& De Santolo, J. (2019). Decolonizing Research: Indigenous Storywork as Methodology. Zed Books.

Argyrou, A., \& Hummels, H. (2019). Legal Personality and Economic Livelihood of Whanganui River: A Call for Community Entrepreneurship. Water International, 44(67), 752-768. https://doi.org/10.1080/02508060.2019.1643525

Banivanua Mar, T. (2012). Settler-Colonial Landscapes and Narratives of Possession. Arena Journal, 37-38, 176-198.

https://search.informit.org/doi/10.3316/INFORMIT.640442097320602

Banivanua Mar, T. (2016). Decolonisation and the Pacific: Indigenous Globalisation and the Ends of Empire. Cambridge University Press. https://doi.org/10.1017/CBO9781139794688

Barad, K. (2007). Meeting the Universe Halfway: Quantum Physics and the Entanglement of Matter and Meaning. Duke University Press. https://doi.org/10.1515/9780822388128

Barlow, J., Franca, F., Gardner, T. A., Hicks, C. C., \& Lennox, G. D. (2018). The Future of Hyperdiverse Tropical Ecosystems. Nature, 559, 517-526. https://doi.org/10.1038/s41586-018-0301-1

Bawaka Country, Wright, S., \& Suchet-Pearson, S. (2015). Co-Becoming Bawaka: Towards a Relational Understanding of Place/Space. Progress in Human Geography, 40(4), 455-475. https://doi.org/10.1177/0309132515589437

Benjamin, R., \& Glaude, E. (2018). [AAS21 Podcast] Episode \#12: Reimagining Science and Technology. Princeton University, Department of African American Studies. https://aas.princeton.edu/news/aas21-podcast-episode-12-reimagining-science-andtechnology

Carrier, J. (1995). Occidentalism: Images of the West. Oxford University Press.

Celermajer, D., Chatterjee, S., Cochrane, A., Fishel, S. R., Neimanis, A., O'Brien, A., Reid, S., Srinivasan, K., Schlosberg, D., \& Waldow, A. (2020). Justice Through a Multispecies Lens. Contemporary Political Theory. 19, 475-512. https://doi.org/10.1057/s41296-02000386-5

Chao, S. (2017). There are no Straight Lines in Nature: Making Living Maps in West Papua. Anthropology Now, 9(1), 16 - 33. https://doi.org/10.1080/19428200.2017.1291014

Chao, S. (2019). Race, Rights, and Resistance: The West Papua Protests in Context. TRT World. https://www.trtworld.com/opinion/race-rights-and-resistance-the-west-papuanprotests-in-context-29515

Chao, S. (2020). A Tree of Many Lives: Vegetal Teleontologies in West Papua. HAU: Journal of Ethnographic Theory, 10(2), 514-529. https://doi.org/10.1086/709505

Chao, S. (2021a). Morethanhuman Matters: An Interview with Dion Enari. More Than Human Worlds. https://www.morethanhumanworlds.com/mthm-dionenari

Chao, S. (2021b). Children of the Palms: Growing Plants and Growing People in a Papuan Plantationocene. Journal of the Royal Anthropological Institute. https://doi.org/10.1111/1467-9655.13489 
eTropic 20.2 (2021) Special Issue: Tropical Imaginaries and Climate Crisis

Chao, S. (2021c). Eating and Being Eaten: The Meanings of Hunger among Marind. Medical Anthropology: Cross-Cultural Studies in Health and IIIness. https://doi.org/10.1080/01459740.2021.1916013

Chao, S. (2021d). Storying Extinction: A Reflection on Loss, Crisis, and Co-existence. Sydney Environment Institute. https://sei.sydney.edu.au/reflection/storying-extinction-areflection-on-loss-crisis-and-co-existence/

Chao, S. (2021e). The Beetle or the Bug? Multispecies Politics in a West Papuan Oil Palm Plantation. American Anthropologist. https://doi.org/10.1112/aman/13592

Chao, S. (2021f). They Grow and Die Lonely and Sad. Fieldsights. https://culanth.org/fieldsights/they-grow-and-die-lonely-and-sad

Chao, S. (2022). In the Shadow of the Palms: More-Than-Human Becomings in West Papua. Duke University Press. (Forthcoming)

Coburn, E., Moreton-Robinson, A., Sefa Dei, G., \& Stewart-Harawira, M. (2013). Unspeakable Things: Indigenous Research and Social Science. Socio, 2, 331-348. https://doi.org/10.4000/socio.524

Davis, H., \& Todd, Z. (2017). On the Importance of a Date, or Decolonizing the Anthropocene. ACME: An International Journal for Critical Geographies, 16(4), 761780. https://www.acme-journal.org/index.php/acme/article/view/1539

de la Cadena, M. (2017). Matters of Method: Or, Why Method Matters Toward a Not Only Colonial Anthropology. HAU: Journal of Ethnographic Theory, 7(2), 1-10. https://doi.org/10.14318/hau7.2.002

Eickelkamp, U., \& Chao, S. (2020). Introducing Oceanic Societies in COVID-19. Oceania, 90(S1), 3-5. https://doi.org/10.1002/ocea.5257

Enari, D. (2021). Methodology Marriage: Merging Western and Pacific Research Design. https://ir.canterbury.ac.nz/bitstream/handle/10092/101590/5\%20Methodology.pdf?sequ ence $=5$

Enari, D., \& Fa'aea, A. M. (2020). E tumau le fa'avae ae fesuia'i faiga: Pasifika Resilience During COVID-19. Oceania, 90(S1), 75-80. https://doi.org/10.1002/ocea.5269

Enari, D. \& Faleolo, R. (2020). Pasifika well-being during the COVID-19 crisis: Samoans and Tongans in Brisbane. Journal of Indigenous Social Development, 110-127 https://journalhosting.ucalgary.ca/index.php/jisd/article/view/70734/54415

Enari, D., \& Matapo, J. (2020). The Digital Vā: Pasifika Education Innovation During the Covid-19 Pandemic. MAl Journal, 9(4), 7-11. https://doi.org/10.20507/MAlJournal.2020.9.4.2

Enari, D., \& Matapo, J. (2021). Negotiating the Relational Vā in the University: A Transnational Pasifika Standpoint During the Covid-19 Pandemic. Journal of Global Indigeneity, 5(1), 1-19. https://www.journalofglobalindigeneity.com/article/19436navigating-the-digital-va-va-centring-moana-pacific-values-in-online-tertiary-settingsduring-covid-19

Enari, D. \& Rangiwai, B. (2021). Digital Innovation and Funeral Practices: Māori and Samoan Perspectives During the COVID-19 Pandemic. Alternative Journal. (Forthcoming)

Escobar, A. (2019). Pluriversal Politics: The Real and the Possible. Duke University Press. https://doi.org/10.1515/9781478012108

Fa'aea, A. M. \& Enari, D. (2021). The Pathway to Leadership is Through Service: Exploring the Samoan Tautua Lifecycle. In Pacific Dynamics: Journal of Interdisciplinary Research. https://ir.canterbury.ac.nz/bitstream/handle/10092/101592/7\%20Tautuafinal.pdf? sequence $=5 \&$ isAllowed $=y$

Fakhruddin, B. S., Babel, M. S., \& Kawasaki, A. (2015). Assessing the Vulnerability of Infrastructure to Climate Change on the Islands of Samoa. Natural Hazards and Earth System Sciences, 15, 1343-1356. https://doi.org/10.5194/nhess-15-1343-2015 
eTropic 20.2 (2021) Special Issue: Tropical Imaginaries and Climate Crisis

Gegeo, D. W., \& Watson-Gegeo, K. A. (2001). "How We Know": Kwara'ae Rural Villagers Doing Indigenous Epistemology. The Contemporary Pacific, 13(1), 55-88. https://doi.org/10.1353/cp. 2001.0004

Gegeo, D. W., \& Watson-Gegeo, K. A. (2002). Whose Knowledge? Epistemological Collisions in Solomon Islands Community Development. The Contemporary Pacific, 14(2), 377-409. https://doi.org/10.1353/cp.2002.0046

Ghosh, A. (2016). Amitav Ghosh: Where is the Fiction about Climate Change? The Guardian. https://www.theguardian.com/books/2016/oct/28/amitav-ghosh-where-is-thefiction-about-climate-change-

Giraud, E. H. (2019). What Comes after Entanglement? Activism, Anthropocentrism, and an Ethics of Exclusion. Duke University Press. https://doi.org/10.1215/9781478007159

Haraway, D. J. (1989). Primate Visions: Gender, Race, and Nature in the Modern World of Science. Routledge.

Haraway, D. J. (2008). When Species Meet. University of Minnesota Press.

Haraway, D. J. (2016). Staying with the Trouble: Making Kin in the Chthulucene. Duke University Press. https://doi.org/10.1215/9780822373780

Harding, S., \& Penny, A. (Eds.). (2020). State of the Tropics. James Cook University.

Hau'ofa, E. (1975). Anthropology and Pacific Islanders. Oceania, 45(4), 283-289. https://doi.org/10.1002/j.1834-4461.1975.tb01871.x

Hau'ofa, E. (2008). We Are the Ocean : Selected Works. University of Hawai'i Press. https://doi.org/10.1515/9780824865542

Hobart, H. J. K., \& Kneese, T. (2020). Radical Care: Survival Strategies for Uncertain Times. Social Text, 38(1), 1-156. https://doi.org/10.1215/01642472-7971067

Howes, D. (2003). Sensual Relations: Engaging the Senses in Culture and Social Theory. The University of Michigan Press. https://doi.org/10.3998/mpub.11852

Kabutaulaka, T. (2020). COVID-19 and Re-Storying Economic Development in Oceania. Oceania, 90(S1), 47-52. https://doi.org/10.1002/ocea.5265

Kimmerer, R. W. (2014). Braiding Sweetgrass: Indigenous Wisdom, Scientific Knowledge, and the Teachings of Plants. Milkweed Press.

Latour, B. (2010). On the Modern Cult of the Factish Gods. Duke University Press.

Law, T. (2019, September 30). The Climate Crisis Is Global, but These 6 Places Face the Most Severe Consequences. TIME. https://time.com/5687470/cities-countries-mostaffected-by-climate-change

Leach, J. (2003). Creative Land: Place and Procreation on the Rai Coast of Papua New Guinea. Berghahn.

Lear, J. (2006). Radical Hope: Ethics in the Face of Cultural Devastation. Harvard University Press.

Lemusuifeauaali'i, E. \& Enari, D. (2021). DUA TANI: (Re)evolving Identities of Pacific Islanders. Te Kaharoa, 17(1). https://doi.org/10.24135/tekaharoa.v17i1.342

Martuwarra RiverofLife, Poelina, A., Bagnall, D., \& Lim, M. (2020). Recognizing the Martuwarra's First Law Right to Life as a Living Ancestral Being. Transnational Environmental Law, 9(3), 541-568. https://doi.org/10.1017/S2047102520000163

Matapo, J. \& Enari, D. (2021). Re-imagining the Dialogic Spaces of Talanoa through Samoan Onto-epistemology. In Waikato Journal of Education. (Forthcoming)

McKittrick, K., \& Woods, C. (Eds.). (2007). Black Geographies and the Politics of Place. South End Press.

Mittermaier, A. (2011). Dreams That Matter: Egyptian Landscapes of the Imagination. University of California Press. https://doi.org/10.1525/9780520947856

Moore, J. W. (2015). Capitalism in the Web of Life: Ecology and the Accumulation of Capital. Verso.

Moore, S. J. (2020). Worlding with Oysters. In E. Castro-Koshy \& G. Le Roux (Eds). 
eTropic 20.2 (2021) Special Issue: Tropical Imaginaries and Climate Crisis

Environmental Artistic Practices and Indigeneity (Special Issue) eTropic: Electronic Journal of Studies in the Tropics, 19(1), 96-104. https://doi.org/10.25120/etropic.19.1.2020.3731

Morton, T. (2013). Hyperobjects: Philosophy and Ecology after the End of the World. University of Minnesota Press.

Nabobo-Baba, U. (2008). Decolonizing Framings in Pacific Research: Indigenous Fijian Vanua Research Framework as an Organic Response. AlterNative: An International Journal of Indigenous Peoples, 4(2), 140-154. https://doi.org/10.1177/117718010800400210

Nugent, C. (2019, July 11). The 10 Countries Most Vulnerable to Climate Change Will Experience Population Booms in the Coming Decades. TIME. https://time.com/5621885/climate-change-population-growth

Pandya, V. (1990). Movement and Space: Andamanese Cartography. American Ethnologist, 17(4), 775 - 797. https://doi.org/10.1525/ae.1990.17.4.02a00100

Perez, C. S. (2020). Poems. In E. Castro-Koshy \& G. Le Roux (Eds). Environmental Artistic Practices and Indigeneity (Special Issue) eTropic: Electronic Journal of Studies in the Tropics, 19(1), 42-64. https://doi.org/10.25120/etropic.19.1.2020.3676

Plumwood, V. (1993). Feminism and the Mastery of Nature. Routledge.

Plumwood, V. (2008). Shadow Places and the Politics of Dwelling. Australian Humanities Review, 44, 139-150. http://australianhumanitiesreview.org/2008/03/01/shadow-placesand-the-politics-of-dwelling/

Plumwood, V. (2009). Nature in the Active Voice. Australian Humanities Review, 46, 113129. http://australianhumanitiesreview.org/2009/05/01/nature-in-the-active-voice

Poelina, A. (2020). A Coalition of Hope! A Regional Governance Approach to Indigenous Australian Cultural Wellbeing. In A. Duffy, M. Campbell, \& B. Edmondson (Eds.), Located Research: Regional Places, Transitions, and Challenges (pp. 153-180). Palgrave. https://doi.org/10.1007/978-981-32-9694-7 10

Popkin, G. (2017). Explaining Tropical Forests' Astonishing Biodiversity. Inside Science. https://www.insidescience.org/news/explaining-tropical-forests-astonishing-biodiversity

Puig de la Bellacasa, M. (2009). Touching Technologies, Touching Visions: The Reclaiming of Sensorial Experience and the Politics of Speculative Thinking. Subjectivity, 28(1), 297 - 315. https://doi.org/10.1057/sub.2009.17

Puig de la Bellacasa, M. (2017). Matters of Care: Speculative Ethics in More Than Human Worlds. University of Minnesota Press. https://www.jstor.org/stable/10.5749/j.ctt1 mmfspt

Quinney, M. (2020). Covid-19 and Nature are Linked. So Should be the Recovery. World Economic Forum. https://www.weforum.org/agenda/2020/04/covid-19-naturedeforestation-recovery

Salisbury, C. (2017). Climate Change Driving Widespread Local Extinctions; Tropics Most at Risk. Mongabay. https://news.mongabay.com/2017/03/climate-change-drivingwidespread-local-extinctions-tropics-most-at-risk

Shotwell, A. (2016). Against Purity. University of Minnesota Press.

Simpson, A. (2007). On Ethnographic Refusal: Indigeneity, "Voice," and Colonial Citizenship. Junctures, 9, 67-80. https://junctures.org/index.php/junctures/article/view/66/60

Singh, J. (2018). Unthinking Mastery: Dehumanism and Decolonial Entanglements. Duke University Press. https://doi.org/10.1215/9780822372363

Stengers, I. (2005). The Cosmopolitical Proposal. In B. Latour \& P. Weibel (Eds.), Making Things Public: Atmospheres of Democracy (pp. 994 - 1003). Massachusetts Institute of Technology Press.

Stengers, I. (2015). In Catastrophic Times: Resisting the Coming Barbarism (A. Goffey (trans.). Open Humanities Press. 
eTropic 20.2 (2021) Special Issue: Tropical Imaginaries and Climate Crisis

http://www.environmentandsociety.org/mml/catastrophic-times-resisting-comingbarbarism

Stewart-Harawira, M. (2012). Returning the Sacred: Indigenous Ontologies in Perilous Times. In R. Roberts \& L. Williams (Eds.), Radical Human Ecology: Intercultural and Indigenous Approaches (pp. 94-109). Taylor \& Francis.

Stewart-Harawira, M. (2013). Challenging Knowledge Capitalism: Indigenous Research in the 21st Century. Socialist Studies, 9(1), 39-51. https://doi.org/10.18740/S43S3V

Stewart-Harawira, M. (2018). Indigenous Resilience and Pedagogies of Resistance: Responding to the Crisis of our Age. In J. B. Kinder \& M. Stewart-Harawira (Eds.), Resilient Systems, Resilient Communities (pp. 158-179). University of Alberta. https://doi.org/10.2139/ssrn.3185625

TallBear, K. (2013). Native American DNA: Tribal Belonging and the False Promise of Genetic Science. University of Minnesota Press. https://doi.org/10.5749/minnesota/9780816665853.001.0001

Teaiwa, K. M. (2019). No Distant Future: Climate Change as Existential Threat. Australian Foreign Affairs, 6, 51-70. https://www.australianforeignaffairs.com/articles/extract/2019/08/no-distant-future

Teaiwa, T. K. (2006). On Analogies: Rethinking the Pacific in a Global Context. Contemporary Pacific Studies, 18(1), 71-87. https://doi.org/10.1353/cp.2005.0105

Teaiwa, T. K., \& Joannemariebarker. (1994). Native Information. Inscriptions, 7, 16-41. https://culturalstudies.ucsc.edu/inscriptions/volume-7/joannemariebarker-teresia-teaiwa

Te Punga Somerville, A. (2021). Canons Don't Only Belong to Dead White Englishmen. We Have a Māori Canon Too. The Guardian.

https://www.theguardian.com/world/2021/feb/14/canons-dont-only-belong-to-deadwhite-englishmen-we-have-a-maori-canon-too

Tsing, A. L. (2005). Friction: An Ethnography of Global Connection. Princeton University Press. https://doi.org/10.1515/9781400830596

Tsing, A. L. (2014). More-Than-Human Sociality: A Call for Critical Description. In K. Hastrup (Ed.), Anthropology and Nature (pp. 27 - 42). Routledge.

Tuck, E. (2009). Suspending Damage: A Letter to Communities. Harvard Educational Review, 79(3), 409-427. https://doi.org/10.17763/haer.79.3.n0016675661t3n15

Tuhiwai Smith, L. (2012). Decolonizing Methodologies: Research and Indigenous Peoples. Zed Books. https://nycstandswithstandingrock.files.wordpress.com/2016/10/lindatuhiwai-smith-decolonizing-methodologies-research-and-indigenous-peoples.pdf

Tui Atua, T. T. T. E. (2003). In Search of Meaning, Nuance, and Metaphor In Social Policy. Social Policy Journal Of New Zealand Te Puna Whakaaro, 20, 49-63.

https://www.msd.govt.nz/about-msd-and-our-work/publications-resources/journals-andmagazines/social-policy-journal/spi20/nuance-and-metaphor-in-social-policy-20pages49-63.html

van Dooren, T. (2014). Flight Ways: Life and Loss at the Edge of Extinction. Columbia University Press E-Book. https://doi.org/10.7312/vand16618

van Dooren, T., \& Rose, D. B. (2016). Lively Ethography: Storying Animist Worlds. Environmental Humanities, 8(1), 77 - 94. https://doi.org/10.1215/22011919-3527731

Vizenor, G. R. (1999). Manifest Manners: Narratives on PostIndian Survivance. University of Nebraska Press.

Wallace-Wells, D. (2019). The Uninhabitable Earth: Life After Warming. Tim Duggan Books. West, P. (2006). Conservation is Our Government Now: The Politics of Ecology in Papua New Guinea. Duke University Press. https://doi.org/10.1215/9780822388067

Whyte, K. P. (2017). Is It Colonial Déjà Vu? Indigenous Peoples and Climate Injustice. In J. Adamson \& M. Davis (Eds.), Humanities for the Environment: Integrating Knowledge, Forging New Constellations of Practice (pp. 88-105). Routledge. 
eTropic 20.2 (2021) Special Issue: Tropical Imaginaries and Climate Crisis

https://www.taylorfrancis.com/books/edit/10.4324/9781315642659/humanitiesenvironment-joni-adamson-michael-davis

Winter, C. (2019). Does Time Colonize Intergenerational Environmental Justice Theory?

Environmental Politics, 29(2), $278-296$.

https://doi.org/10.1080/09644016.2019.1569745

Winter, C., \& Troy, J. (2020). Indigenous Justice in Times of Climate Crisis. Sydney

Environment Institute. https://sei.sydney.edu.au/opinion/indigenous-justice-in-times-ofclimate-crisis

\section{Acknowledgments}

Sophie Chao thanks the Marind communities of Merauke, the NGO PUSAKA, and the Merauke Secretariat for Peace and Justice for their hospitality, generosity, and support throughout her fieldwork in West Papua. Funding for this research was received from the Wenner-Gren Foundation for Anthropological Research, Macquarie University's Department of Anthropology, and the University of Sydney's Faculty of Arts and Social Sciences and Charles Perkins Centre. Dion Enari thanks Tagaloa Dr Glenda Stanley and Innez Fainga'a Manu-Sione for their academic support and writing retreats, the Brisbane Samoan community and his villages of Lepa, Malaela, Vaiala, Nofoali'i and Safune. Both authors acknowledge with respect the many soils, waters, species, and landscapes that have, and continue, to nurture, nourish, and sustain us.

Dr Sophie Chao is a Postdoctoral Research Associate at the University of Sydney's School of Philosophical and Historical Inquiry. Her research explores the intersections of Indigeneity, ecology, capitalism, health, and justice in the Pacific. Chao previously worked for human rights organisation Forest Peoples Programme. She holds a Bachelor of Arts in Oriental Studies and a Master of Science in Social Anthropology from the University of Oxford and a PhD in Anthropology from Macquarie University. For more information, please visit www.morethanhumanworlds.com.

Dion Enari is a Lecturer at the School of Sport and Recreation, Faculty of Health and Environmental Sciences at Auckland University of Technology. He is also a PhD Candidate at Bond University, Australia with a Master of International Relations and Lefaoali'i (high talking Chief) title from Lepa, Samoa. His research interests include Sport Management, Sport Leadership, mental health, Pacific language, indigenous studies, and trans-nationalism. For more information, please visit https://www.linkedin.com/in/lefaoalii-dion-enari-b730a7149/. 